\title{
PRELIMINARY MOLECULAR PHYLOGENETICS OF SOBRALIA AND RELATIVES (ORCHIDACEAE: SOBRALIEAE)
}

\author{
Kurt M. Neubig ${ }^{1,2,5}$, W. Mark Whitten ${ }^{2}$, Mario A. Blanco ${ }^{1,2,3}$, Lorena Endara ${ }^{1,2}$, \\ Norris H.Williams ${ }^{2} \&$ Samantha Koehler ${ }^{4}$ \\ ${ }^{1}$ Department of Biology, University of Florida, Gainesville, Florida 32611-8526, U.S.A. \\ ${ }^{2}$ Florida Museum of Natural History, University of Florida, P. O. Box 117800, Gainesville, \\ Florida 32611-7800, U.S.A. \\ ${ }^{3}$ Jardín Botánico Lankester, Universidad de Costa Rica, Apdo. 1031-7050, Cartago, Costa Rica \\ ${ }^{4}$ Departamento Ciências Biológicas, Universidade Federal de São Paulo, Diadema, \\ SP, 09972-270, Brazil \\ ${ }^{5}$ Corresponding author: kneubig@flmnh.ufl.edu
}

\begin{abstract}
With over 200 species, the orchid tribe Sobralieae is a major constituent of the Neotropical flora. As currently circumscribed, the tribe includes four genera: Elleanthus, Epilyna, Sertifera, and Sobralia. Most species of these four genera typically produce long, cane-like stems but differ drastically in flower size and inflorescence structure. DNA sequence data support the monophyly of Elleanthus, Epilyna, and Sertifera but not Sobralia, which is a polyphyletic assemblage traditionally placed together due to relatively large flower size. Details of inflorescence structure provide characters that can easily distinguish the different clades of Sobralia. The misleading characteristic of flower size is probably due to at least several shifts in pollination syndrome within the tribe. With few exceptions, species of Sobralia predominantly offer no reward and are pollinated by bees. Elleanthus and Sertifera are small-flowered and mostly pollinated by hummingbirds with legitimate rewards. Nothing is known of pollination in Epilyna. Understanding the evolution of shifts in pollination syndrome will require more empirical observations of pollination within Sobralieae. In addition, increased taxon sampling and improved phylogenetic resolution are needed before generic realignments are made.
\end{abstract}

Resumen. Con más de 200 especies, la tribu de orquídeas Sobralieae es un componente importante de la riqueza florística de los neotrópicos. Actualmente esta tribu está constituída por cuatro géneros: Elleanthus, Epilyna, Sertifera, y Sobralia. Las plantas de éstos cuatro géneros generalmente producen tallos largos como cañas, pero difieren en forma drástica en el tamaño de la flor y la estructura de las inflorescencias. Datos de ADN apoyan la monofilia de Elleanthus, Epilyna, y Sertifera, pero no de Sobralia. Sobralia es un ensamblaje polifilético, tradicionalmente circunscrito por el gran tamaño de sus flores. Los detalles de la morfología floral y la posición de la inflorescencia proporcionan caracteres que fácilmente permiten distinguir los diferentes clados de Sobralia. El tamaño de la flor y ciertas otras características superficiales probablemente han sufrido cambios evolutivos en respuesta a cambios en el síndrome de polinización dentro de la tribu. La mayoría de las especies de Sobralia no ofrecen ninguna recompensa y son polinizadas por abejas en busca de néctar. Elleanthus y Sertifera tienen flores pequeñas que aparentemente son polinizadas por colibríes, en estos dos géneros las flores ofrecen néctar. No se conoce nada sobre la polinización de Epilyna. Mas observaciones empíricas de los polinizadores de Sobralieae son necesarias para entender la evolución de los síndromes de polinización, y requerirá un mayor muestreo de especies y una mejor resolución filogenética antes de realizar recircumscripciones genéricas.

Key words: Orchidaceae, Sobralieae, Sobralia, phylogenetics

Tribe Sobralieae, described by Pfitzer in 1887, has long been recognized as a natural group, at least in part. For part of its nomenclatural history it has been known as subtribe Sobraliinae (although placed in several different tribes). Dressler (1981) placed his subtribe Sobraliinae in tribe Arethuseae based on 
symplesiomorphies such as presence of corms, plicate leaves, and eight soft pollinia (although he also included aberrant genera such as Arpophyllum and Xerorchis). Dressler (1993) later placed subtribe Sobraliinae in tribe Epidendreae based on the distinctive velamen and seed morphology. In general, variation in taxonomic placement of Sobralieae has been associated with other basal members of subfamily Epidendroideae based on plesiomorphic subfamilial characters. More recent and objective phylogenetic analyses using DNA data have demonstrated that Sobralieae are basal members of the subfamily Epidendroideae, closely related to genera such as Tropidia (Cameron et al., 1999; Cameron, 2002, 2004). Because this group is not closely related to other taxa in tribes Epidendreae and Arethuseae, the former subtribe Sobraliinae is now recognized as a tribe (see Pridgeon et al., 2005).

Tribe Sobralieae consists of only four genera of unequal species richness. Two genera, Elleanthus C.Presl. and Sobralia Ruiz \& Pav., each consist of about 100 species, whereas the other two genera, Epilyna Schltr. and Sertifera Lindl. \& Rchb.f., each consist of less than 10 species. The tribe as a whole is widely distributed in tropical America. Sertifera is restricted to relatively high elevations in the northern Andes. Epilyna is found in southern Central America and northern South America. Elleanthus is distributed throughout tropical America, and Sobralia is similar in distribution except for notable absence in the West Indies.

Although some vegetative traits are useful for identifying species or groups within Sobralieae, there is ample homoplasy in vegetative morphology among distantly related taxa. Genera have been delimited on the basis of relatively few gross floral characters (Fig. 1). Sobralia has largely been recognized based on relatively large flowers. The other three genera (Elleanthus, Epilyna, Sertifera) all have relatively small flowers. This criterion is misleading and has been shown to result in the circumscription of polyphyletic groups based on homoplasious character evolution (e.g., Johnson et al., 1998). Because there has been such a poor understanding of generic circumscription in Sobralieae and no robustly taxonsampled phylogenetic analysis of the tribe, we addressed phylogenetic relationships within the tribe. We hypothesized that floral size would not be adequate for reciprocal monophyly in these genera because the polarity of such a character would make one state symplesiomorphic. Therefore, the purpose of this study was to provide a phylogenetic framework in which to understand the evolution of morphological variation in tribe Sobralieae.

\section{Materials and methods}

Taxon sampling - Specimens were obtained from wild-collected and cultivated plants (Table 1). Sampling of Elleanthus, Epilyna, Sertifera, and Sobralia included 42 species. Outgroups included three other genera of basal Epidendroid tribes Neottieae (Palmorchis), Arethuseae (Bletilla), and Tropidieae (Tropidia). Outgroups were chosen based on phylogenetic placement of Sobralia and Elleanthus in previous work (Cameron et al., 1999; Cameron, 2002; Chase et al., 2003; Cameron, 2004).

Extractions, amplification and sequencing -All freshly collected material was preserved in silica gel (Chase \& Hills, 1991). Genomic DNA was extracted using a modified cetyl trimethylammonium bromide (CTAB) technique (Doyle \& Doyle, 1987), scaled to a $1 \mathrm{~mL}$ volume reaction. Approximately $10 \mathrm{mg}$ of dried tissue were ground in $1 \mathrm{~mL}$ of CTAB $2 \mathrm{X}$ buffer and either $8 \mu \mathrm{L}$ of $\beta$-mercaptoethanol or $10 \mu \mathrm{L}$ of proteinase-K. Some total DNAs were then cleaned with Qiagen QIAquick PCR purification columns to remove any inhibitory secondary compounds. Amplifications were performed using a Biometra Tgradient or an Eppendorf Mastercycler EP Gradient S thermocycler and Sigma brand reagents in $25 \mu \mathrm{L}$ volumes with the following reaction components for ITS: $0.5-1.0 \mu \mathrm{L}$ template DNA ( 10-100 ng), $11 \mu \mathrm{L}$ water, $6.5 \mu \mathrm{L} 5 \mathrm{M}$ Betaine, $2.5 \mu \mathrm{L} \mathrm{10X}$ buffer, $3 \mu \mathrm{L} \mathrm{MgCl} 2(25 \mathrm{mM}), 0.5 \mu \mathrm{L}$ of 10 $\mu \mathrm{M}$ dNTPs, $0.5 \mu \mathrm{L}$ each of $10 \mu \mathrm{M}$ primers, and 0.5 units Taq. For the plastid regions the following reaction components were used: $0.5-1.0 \mu \mathrm{L}$ template DNA ( 10-100 ng), 16-17.5 $\mu \mathrm{L}$ water, $2.5 \mu \mathrm{L} 10 \mathrm{X}$ buffer, 2-3 $\mu \mathrm{L} \mathrm{MgCl} 2(25 \mathrm{mM}), 0.5 \mu \mathrm{L}$ of $10 \mu \mathrm{M}$ dNTPs, 0.5 $\mu \mathrm{L}$ each of $10 \mu \mathrm{M}$ primers, and 0.5 units Taq.

nrITS (ITS $1+5.8 \mathrm{~S}$ rDNA+ ITS 2) - This region was amplified with a touchdown protocol using the parameters $94 \mathrm{C}, 2 \mathrm{~min}$; 15X (94 C, $1 \mathrm{~min}$; $76 \mathrm{C}, 1$ min, reducing $1 \mathrm{C}$ per cycle; $72 \mathrm{C}, 1 \mathrm{~min}) ; 21 \mathrm{X}$ (94 C, $1 \mathrm{~min} ; 59 \mathrm{C}, 1 \mathrm{~min} ; 72 \mathrm{C}, 1 \mathrm{~min}) ; 72 \mathrm{C}, 3$ min with the 


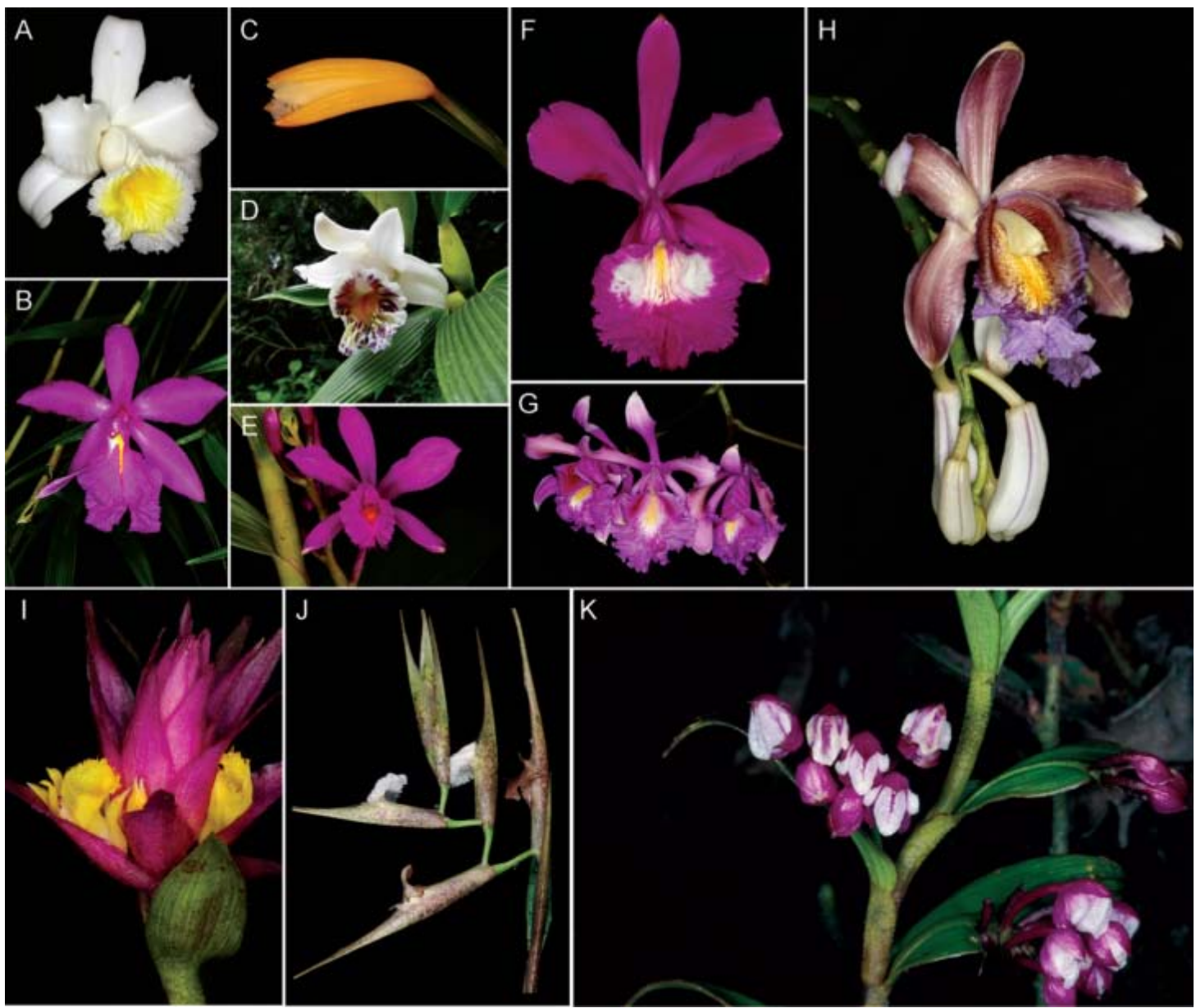

FIgURE 1. Floral diversity of tribe Sobralieae. There is extensive variation in the "core" group of Sobralia, such as in A) $S$. citrea, B) S. callosa, C) S. crocea, and D) S. luerorum. Various members of Sobralia sect. Sobralia include E) S. ciliata, F) $S$. portillae, G) S. mandonii, and H) S. caloglossa (not sampled in this study, but unpublished data place this species in a clade with $S$. mandonii and $S$. dichotoma). Most members of the genus Elleanthus have brightly colored bracts and flowers as in I) E. caravata, but some species have small white flowers and brownish bracts as in J) E. lancifolius. K) Species of the genus Sertifera all have flowers that are brightly colored pink and white.

primers 17SE (ACG AAT TCA TGG TCC GGT GAA GTG TTC G) and 26SE (TAG AAT TCC CCG GTT CGC TCG CCG TTA C) from Sun et al. (1994).

$\operatorname{trn} S^{G C U}-\operatorname{trn} G^{U C C}$ - This region was amplified with the parameters $94 \mathrm{C}, 3 \mathrm{~min} ; 33 \mathrm{X}(94 \mathrm{C}, 30 \mathrm{sec} ; 50 \mathrm{C}$, $30 \mathrm{sec} ; 72 \mathrm{C}, 2 \mathrm{~min}) ; 72 \mathrm{C}, 3 \mathrm{~min}$, with the primers trnSGCU (AGA TAG GGA TTC GAA CCC TCG GT) and 3 'trnG GUC (GTA GCG GGA ATC GAA CCC GCA TC) from Shaw et al. (2005).

$y c f 1$ - We sequenced a ca. 1500 base-pair (bp) portion from the 3' end (Neubig et al., 2009). This region was amplified using a "touchdown" protocol with the parameters $94 \mathrm{C}, 3 \mathrm{~min}$; $8 \mathrm{X}$ (94 C, $30 \mathrm{sec}$; 60-51 C, 1 min; 72 C, $3 \mathrm{~min}$ ); $30 \mathrm{X}$ (94 C, $30 \mathrm{sec} ; 50 \mathrm{C}, 1 \mathrm{~min} ; 72$ C, 3 min); 72 C, 3 min, with primers 3720 F (TAC GTA TGT AAT GAA CGA ATG G) and 5500R (GCT GTT ATT GGC ATC AAA CCA ATA GCG). Additional internal primers intF (GAT CTG GAC CAA TGC ACA TAT T) and intR (TTT GAT TGG GAT GAT CCA AGG) were also required for sequencing.

PCR products were cleaned with Microclean ${ }^{\mathrm{TM}}$ (The Gel Company, San Francisco, CA, USA) following the manufacturer's protocols, eluted with $50 \mu \mathrm{L}$ of $10 \mathrm{mM}$ Tris- $\mathrm{HCl}(\mathrm{pH} 8.5)$ and stored at 4 C. Purified 
TABLE 1. Species names and voucher information, including herbarium of voucher deposition, for material used in this study.

\begin{tabular}{|c|c|}
\hline Taxon & Voucher \\
\hline Bletilla striata (Thunb. ex Murray) Rchb.f. & Neubig 1-2006 (FLAS) \\
\hline Elleanthus aurantiacus (Lindl.) Rchb.f. & Whitten 1611 (FLAS) \\
\hline Elleanthus capitatellus Dressler & Neubig 201 (FLAS) \\
\hline Elleanthus caricoides Nash & Blanco 3106 (FLAS) \\
\hline Elleanthus caravata (Aubl.) Rchb.f. & Neubig 202 (FLAS) \\
\hline Elleanthus conifer (Rchb.f. \& Warsz.) Rchb.f. & Blanco 2527 (FLAS) \\
\hline Elleanthus cynarocephalus (Rchb. f.) Rchb.f. & Blanco 3105 (FLAS) \\
\hline Elleanthus lancifolius C.Presl & Blanco 2918 (FLAS) \\
\hline Elleanthus oliganthus (Poepp. \& Endl.) Rchb.f. & Whitten 2861 (FLAS) \\
\hline Elleanthus cf. virgatus (Rchb.f.) C. Schweinf. & Whitten 1740 (FLAS) \\
\hline Elleanthus cf. purpureus (Rchb.f.) Rchb.f. & Whitten 3538 (FLAS) \\
\hline Elleanthus stolonifer Barringer & Blanco 2934 (FLAS) \\
\hline Elleanthus tricallosus Ames \& C.Schweinf. & Blanco 2961 (FLAS) \\
\hline Epilyna hirtzii Dodson & Whitten 2938 (FLAS) \\
\hline Epilyna jimenezii Schltr. & Blanco 2997 (FLAS) \\
\hline Palmorchis powellii (Ames) C.Schweinf. \& Correll & Vargas 2115 (INB) \\
\hline Sertifera colombiana Schltr. & Whitten 2937 (FLAS) \\
\hline Sobralia allenii L.O.Williams & Whitten 2834 (FLAS) \\
\hline Sobralia bouchei Ames \& C.Schweinf. & Blanco 3000 (FLAS) \\
\hline Sobralia callosa L.O.Williams & Blanco 3021 (FLAS) \\
\hline Sobralia chrysostoma Dressler & Neubig 213 (FLAS) \\
\hline Sobralia ciliata (C. Presl) C.Schweinf. \& Foldats & Whitten 3529 (FLAS) \\
\hline Sobralia citrea Dressler & Blanco 3030 (FLAS) \\
\hline Sobralia crispissima Dressler & Whitten 2973 (FLAS) \\
\hline Sobralia crocea (Poepp. \& Endl.) Rchb.f. & Whitten 1578 (FLAS) \\
\hline Sobralia decora Bateman & Whitten 2862 (FLAS) \\
\hline Sobralia dichotoma Ruiz \& Pav. & Whitten 3532 (FLAS) \\
\hline Sobralia dorbignyana Rchb.f. & Trujillo 276 (HURP) \\
\hline Sobralia klotzscheana Rchb.f. & Blanco 3011 (FLAS) \\
\hline Sobralia labiata Warsz. \& Rchb.f. & Whitten 2832 (FLAS) \\
\hline Sobralia lancea Garay & Whitten 2869 (FLAS) \\
\hline
\end{tabular}




\begin{tabular}{|c|c|}
\hline Taxon & Voucher \\
\hline Sobralia leucoxantha Rchb.f. & Blanco 2675 (FLAS) \\
\hline Sobralia liliastrum Lindl. & Koehler 34146 (ESA) \\
\hline Sobralia luerorum Dodson & Whitten 2729 (FLAS) \\
\hline Sobralia macrophylla Rchb.f. & Blanco 3022 (FLAS) \\
\hline Sobralia mandonii Rchb. f. & Whitten 3247 (FLAS) \\
\hline Sobralia mucronata Ames \& C.Schweinf. & Blanco 2971 (FLAS) \\
\hline Sobralia portillae Christenson & Whitten 2433 (FLAS) \\
\hline Sobralia quinata Dressler & Pupulin 3644 (USJ-L) \\
\hline Sobralia recta Dressler & Whitten 2851 (FLAS) \\
\hline Sobralia rosea Poepp. \& Endl. & unvouchered \\
\hline Sobralia undatocarinata C.Schweinf. & Maduro \& Olmos 227(FLAS) \\
\hline Sobralia warscewiczii Rchb f. & Blanco 2676 (FLAS) \\
\hline Sobralia yauaperyensis Barb.Rodr. & Blanco 3023 (FLAS) \\
\hline Tropidia polystachya (Sw.) Ames & Whitten 2830 (FLAS) \\
\hline
\end{tabular}

PCR products were then cycle-sequenced using the parameters $96 \mathrm{C}, 10 \mathrm{sec}$; $25 \mathrm{X}(96 \mathrm{C}, 10 \mathrm{sec} ; 50 \mathrm{C}$, $5 \mathrm{sec} ; 60 \mathrm{C}, 4 \mathrm{~min}$ ), with mix of $3 \mu \mathrm{L}$ water, $1 \mu \mathrm{L}$ fluorescent Big Dye dideoxy terminator, $2 \mu \mathrm{L}$ Better Buffer $^{\mathrm{TM}}$ (The Gel Company), $1 \mu \mathrm{L}$ template and 0.5 $\mu \mathrm{L}$ primer. Cycle sequencing products were cleaned using ExoSAPTM (USB Corporation, OH, USA) following the manufacturer's protocols. Purified cycle sequencing products were directly sequenced on an ABI 377,3100 or 3130 automated sequencer according to the manufacturer's protocols (Applied Biosystems, Foster City, CA, USA). Electropherograms were edited and assembled using Sequencher 4.9 ${ }^{\mathrm{TM}}$ (GeneCodes, Ann Arbor, MI, USA). All sequences were deposited in GenBank (Table 1).

Data analysis - Sequence data were manually aligned using Se-Al v2.0a11 (Rambaut, 1996). No sequence data were excluded from analyses. Indels (insertions/ deletions) were not coded as characters. Analyses were performed using PAUP*4.0b10 (Swofford, 1999). Fitch parsimony (unordered characters with equal weights; Fitch, 1971) analyses used a heuristic search strategy consisted of branch swapping by tree bisection reconnection (TBR), Deltran character optimization, stepwise addition with 1000 randomaddition replicates holding 5 trees at each step, and saving multiple trees (MulTrees). Levels of support were assessed using the bootstrap (Felsenstein, 1985). Bootstrap percentages under parsimony were estimated with 1000 bootstrap replicates, using TBR swapping for 50 randomaddition replicates per bootstrap replicate. For maximum likelihood (ML), Modeltest (Posada \& Crandall, 1998) was used to determine the appropriate model for analysis using all combined data under the Akaike Information Criterion. ML analyses were performed using a $\mathrm{Tr} \mathrm{N}+\mathrm{I}+\Gamma$ model for the ITS data set, a K81uf $+\mathrm{I}+\Gamma$ model for the combined plastid data set, and TIM $+\mathrm{I}+\Gamma$ model for the combined three-gene data set. Bootstrap percentages under ML were estimated with 100 bootstrap replicates, using TBR swapping for one random- addition replicate per bootstrap replicate.

All analyses were performed for data sets including ITS only, plastid only, and all data combined. Data congruence was tested using the partition homogeneity test (HTF) in PAUP*4.0b10 (Swofford, 1999) as described by Johnson and Soltis (1998). Heuristic 

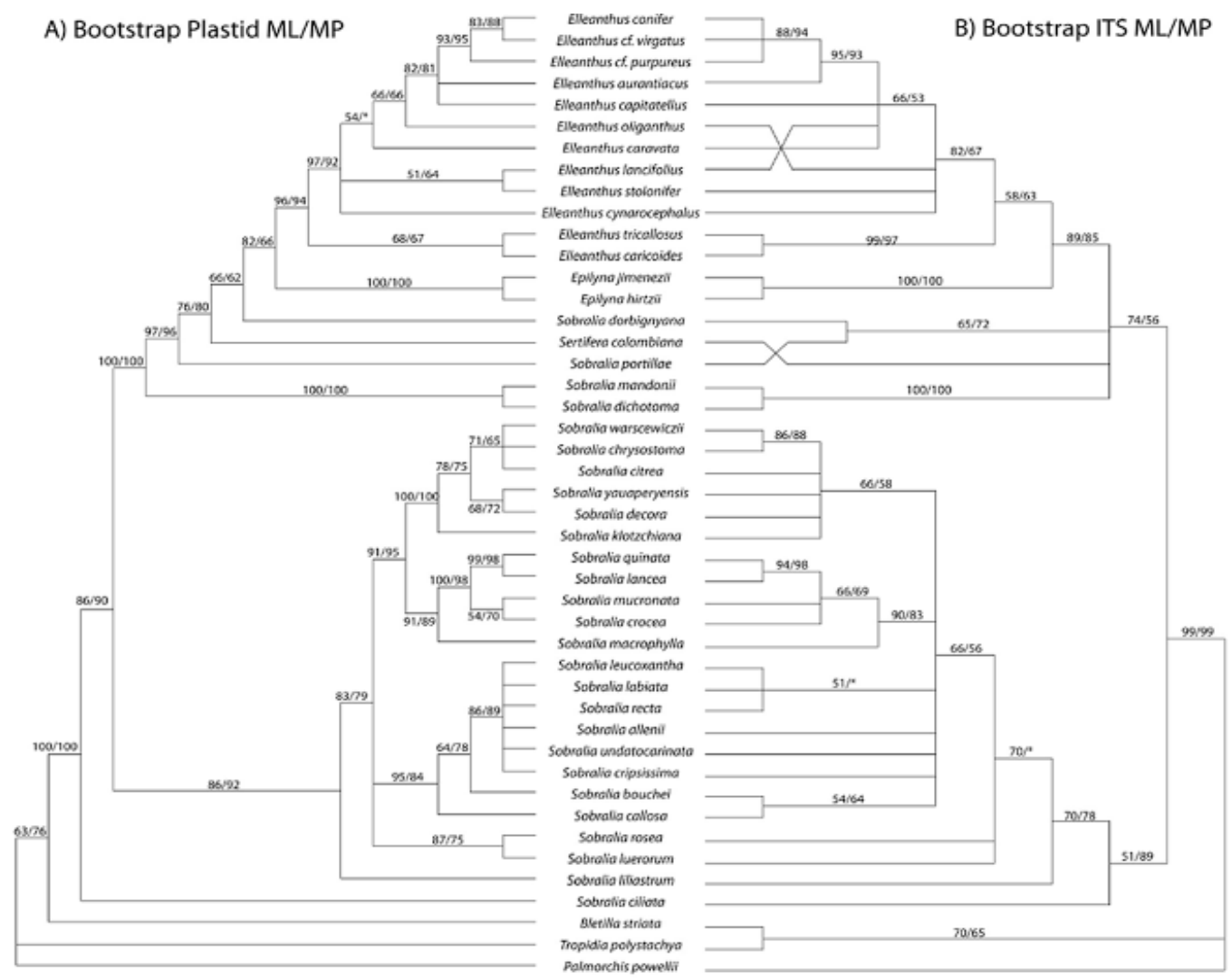

FIGURE 2. Comparative phylogenetic structure among data partitions in Sobralieae. A) From combined plastid data set (ycf1 and $\operatorname{trn} S-G$ ). B) From nuclear ribosomal internal transcribed spacer (ITS). Numbers above or below branches indicate maximum likelihood and parsimony bootstrap percentages, respectively. An asterisk represents bootstrap support of less than $50 \%$.

searches for the HTF tests were performed using 100 replicates and TBR branch-swapping. Probability values lower than 0.05 were used to identify data sets that were significantly different from one another.

\section{Results}

The aligned length of the ITS data set was $892 \mathrm{bp}$. Of these, 222 were parsimonyinformative $(24.9 \%)$. Fitch parsimony analysis of the ITS region found 100 equally parsimonious trees of 798 steps (consistency index $(\mathrm{CI})=0.589$, retention index $(\mathrm{RI})=0.753)$. The aligned length of the combined plastid data set (trnS-G and $y c f 1$ ) data set was 2919 bp. Of these, 250 were parsimony-informative (8.6\%). Fitch parsimony analysis of the combined plastid data set found 100 equally parsimonious trees of 1112 steps $(\mathrm{CI}=0.772$, $\mathrm{RI}=0.794)$. The aligned length of the combined (three
DNA regions) data set (ITS, trnSG, and $y c f 1$ ) was $3811 \mathrm{bp}$. Of these, 472 were potentially parsimonyinformative (12.4\%). Parsimony analysis of all three DNA regions found 36 equally parsimonious trees of 1926 steps $(\mathrm{CI}=0.690, \mathrm{RI}=0.767)$.

Maximum likelihood analysis of ITS only (not presented), plastid data only (not presented), and all three regions $(-\operatorname{lnL}=16599.46)$ yielded trees similar in topology to parsimony. Bootstrap support for all nodes was similar to that from parsimony. The only exception is in the relative placement of Sobralia ciliata in plastid versus ITS data (Fig. 2).

Partition homogeneity tests showed mixed results for congruence among the different partitions of these data. The test comparing ITS and the combined plastid data showed significant incongruence compared with random partitions of the same size $(\mathrm{P}=0.03, \alpha=0.05)$. 
However, various combinations of each of the three individual data sets did not indicate significant incongruence (ITS/trnS- $G \mathrm{P}=0.10$; ITS/ycf1 $\mathrm{P}=0.13$; $y c f 1 / t r n S-G \mathrm{P}=0.05)$. A visual comparison of bootstrap percentages between the different data sets (Fig. 2) indicates that there are only a few examples of strong incongruence. For example, Sobralia ciliata is sister to the "core" group of Sobralia according to ITS but sister to the rest of the tribe in the plastid data set. Other incongruencies can be found in the relative positions of S. dorbignyana, S. portillae, S. mandonii, S. dichotoma, and Sertifera colombiana. All data were combined because the partition homogeneity test has been demonstrated to be overly sensitive (Graham et al., 1998; Reeves et al., 2001) and because a total evidence approach yields highly resolved and relatively strongly supported topology.

With limited outgroup taxon sampling, relationships among the basal Epidendroideae tribes Neottieae (Palmorchis), Tropidieae (Tropidia), Arethuseae (Bletilla), and Sobralieae remain unclear. However, tribe Sobralieae is monophyletic in all data sets.

Within Sobralieae, there are many consistent features among different data sets. The "core" group of Sobralia (see Fig. 3, 4), Elleanthus, and Epilyna are all consistently monophyletic. Because only one sample of Sertifera was used in this study, monophyly of the genus could not be determined. Inconsistent features of phylogenetic topology are centered on Sobralia species within section Sobralia: S. dichotoma, S. ciliata, S. dorbignyana, S. mandonii, and S. portillae. These species have basal positions within the trees; however, their relative position to each other varies among different data sets.

\section{Discussion}

Morphological characters supporting the monophyly of Sobralieae include an elongate cane-like stem and flowers with two calli at the base of the lip. Within Sobralieae, Elleanthus and Epilyna are both monophyletic, but Sobralia is polyphyletic. We sought morphological features that might distinguish the various clades that have been taxonomically included in Sobralia. These features are discussed below.

Inflorescence structure - Inflorescences in Sobralieae may be axillary or terminal. Terminal inflorescences are formed at the apex of a shoot and axillary inflorescences are borne from axillary buds, basal to the shoot terminus. The distinction between these two positions can be blurred in some plant groups, but in Sobralieae, the difference is usually clear (see Fig. 1, 4 for variation in inflorescence structure). However, in a few species (e.g., Sobralia dorbygniana), both terminal and axillary inflorescences are produced because the inflorescence is a compound panicle. Inflorescences also have bracts (leaf-derived structures), and these can vary in size and shape. Furthermore, the axis of an inflorescence (i.e., the rachis) may be highly condensed (capitate in some species of Elleanthus) or elongate, branched or unbranched, erect or (less commonly) nodding, and may have either spiral or distichous phyllotaxy. In a few species of Elleanthus, specialized short shoots with reduced leaves bear the (terminal) inflorescences, whereas the taller, leafy shoots do not produce inflorescences at all.

In Sobralieae, all of these inflorescence structural variants exist in some combination. These differences are presented in the simplified illustrations of Figure 4. As delimited in Figure 3, the "core Sobralia" is a group distinguished by two main types of inflorescence morphology. Both types are terminal, but in species such as $S$. rosea and $S$. luerorum ( $S$. sect. Racemosae) the floral displays are strongly distichous and the rachis is fractiflex ("zigzag") with relatively large bracts. Sobralia liliastrum also has this inflorescence morphology, and when combined with S. rosea and S. luerorum, this assemblage is paraphyletic. In the remainder of "core Sobralia," the inflorescence rachis is highly condensed, such that the internodes of the rachis are extremely short (often 1-2 mm). The resulting morphology appears acaulescent with relatively large bracts. This condensed inflorescence is present in many Sobralia with ephemeral flowers.

In the combined analysis (Fig. 3, 4), Sobralia ciliata is sister to "core Sobralia," whereas $S$. dichotoma and S. mandonii are sister to the remainder of the tribe. These three species have all been placed in $S$. sect. Sobralia. In addition to the genus Sertifera, these species all have axillary inflorescences that may or may not branch to form panicles as well as relatively small inflorescence bracts. Two additional species of 


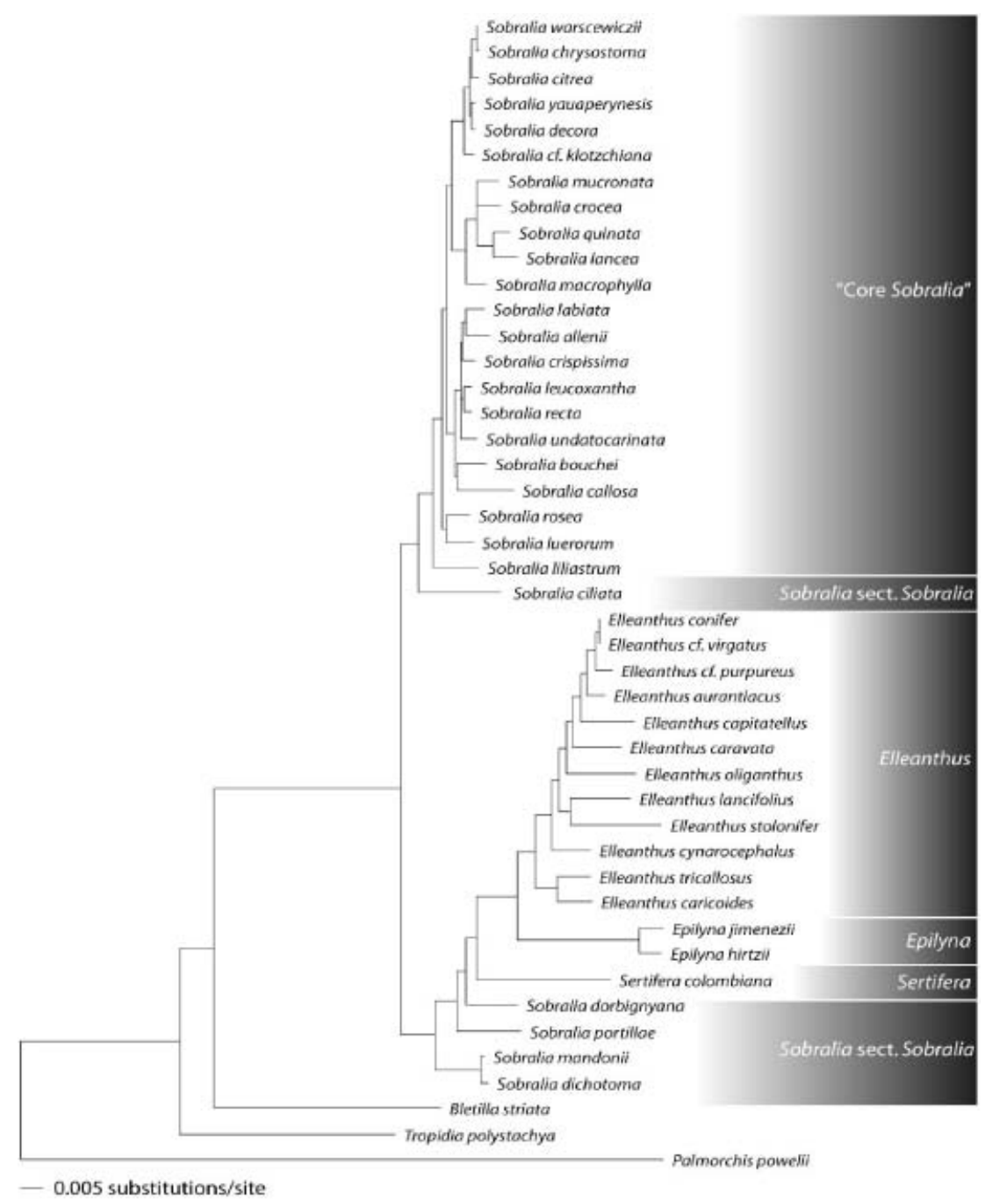

FIgURE 3. The single tree (phylogram) of Sobralieae found in a heuristic maximum likelihood search usingn all three DNA regions (ITS, trnS-G, and $y c f 1$ ).

S. sect. Sobralia (S. dorbignyana and S. portillae) have terminal inflorescences. This feature is shared with virtually all species of Epilyna and Elleanthus. Elleanthus has the most variable inflorescences in the whole tribe. Elleanthus inflorescences can be distichous or spirally arranged, capitate to loosely racemose, and can be oriented downwards, upwards or even horizontally (parallel to the ground).

The evolutionary trends in each of the two large clades of Sobralieae demonstrate the plesiomorphic condition of axillary inflorescences. This apparently symplesiomorphic grade across both major clades is represented by some taxa of $S$. sect. Sobralia and Sertifera. The result is that there has been independent convergence to terminal inflorescences across both large clades in Sobralieae.

Flower size - There is a great range in flower size of Sobralieae. Species of Elleanthus, Epilyna, and Sertifera have relatively small flowers compared to the flowers of Sobralia. Variation in floral size is likely a consequence of shifts in pollination mode. The large flowers of Sobralia are mostly pollinated by large bees (e.g. Eulaema). The small flowers of 


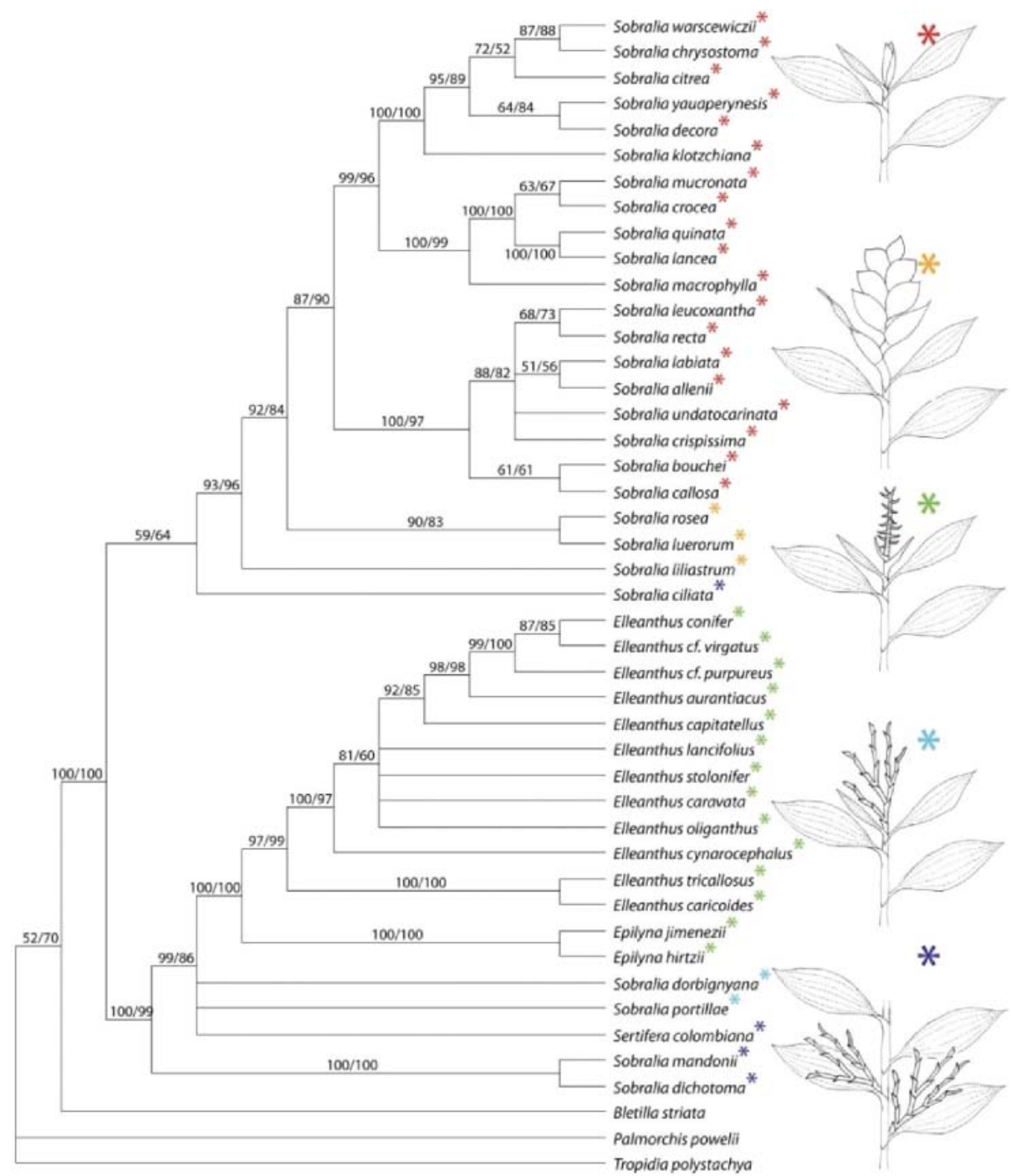

FiguRE 4. Bootstrap consensus tree of Sobralieae using all three DNA regions (ITS, $\operatorname{trn} S$ - $G$, and $y c f 1$ ), to demonstrate relative support for clades. Numbers above or below branches indicate maximum likelihood and parsimony bootstrap percentages, respectively. Colored asterisks indicate distribution of major inflorescence morphology among taxa (n.b., inflorescences are especially variable in Elleanthus, ranging from fractiflex to spiral and loosely racemose to capitate but are always terminal and consisting of a single axis as indicated by the illustration).

Elleanthus and Sertifera are usually pollinated by hummingbirds. However, pollinators of Epilyna and those of smaller, white-flowered species of Elleanthus, are unknown.

Variation of different pollinators and associated floral morphologies have been well documented in some systems (Thomson and Wilson, 2008). However, there are also taxonomic implications for shifts in pollination syndrome. Often, species or groups of species that have shifted to a different syndrome have been traditionally placed in different genera. This nomenclatural bias to recognize genera because of variation in gross floral morphology has been demonstrated to conflict with phylogenetic relationships due to homoplasy in pollination- related floral characters. This bias is particularly apparent within Sobralia. Sobralia callosa has been segregated as Lindsayella Ames \& C.Schweinf. because of its 
distinctive hummingbird-floral syndrome, as opposed to the typical bee-floral syndrome that is characteristic of most species of Sobralia. However, the recognition of Lindsayella would elevate the degree of polyphyly in Sobralia. The floral morphology is misleading in this example because "distinctiveness" does not connote reciprocal monophyly.

In a larger phylogenetic context, relatively large flowers are plesiomorphic within the tribe, and generic concepts should not be based primarily on flower size. However, flower size combined with inflorescence position and structure are diagnostic, and we recommend that future generic recircumscriptions be based on the combination of these apomorphic characters in conjunction with molecular data. Unfortunately, the type species of Sobralia is S. dichotoma (designated by Angely in Fl. Analítica São Paulo 6: 1268. 1973). This species does not belong to "core Sobralia" as defined in this paper. As a result of this quirk of history and because of the polyphyly of Sobralia, there are problematic nomenclatural issues with tribe Sobralieae. However, this problem is best resolved with more data and will be the subject of future research.

ACKNowledgments. We thank Jardín Botánico Lankester (Universidad de Costa Rica) for contributing vouchered specimens and tissue. We are grateful to the Portilla family of Ecuagenera Ltd. in Gualaceo, Ecuador, and to Andy Phillips of Andy's Orchids in Encinitas, California, for generous access to their collections. Some specimens were generously provided by Delsy Trujillo. Robert Dressler helped with identification and provision of specimens. Barbara Sue Carlsward provided technical support. Computation time was provided by the FLMNH Phyloinformatics Cluster for High Performance Computing in the Life Sciences funded by grants from the U.S. National Science Foundation awarded to Pam and Doug Soltis with technical assistance provided by Matt Gitzendanner. We also thank Savita Shanker and Patrick Thimote at the Interdisciplinary Center for Biotechnology Research at University of Florida. Specimen curation has been provided primarily by Kent Perkins at the FLAS herbarium in the Florida Museum of Natural History. Portions of this research were funded by the Lewis and Varina Vaughn Fellowship in Orchid Biology, the American Orchid Society's 11th World Orchid Conference Fellowship to K. Neubig, and the U.S. National Science Foundation grant No. DEB-234064 to N. H. Williams and W. M. Whitten.

\section{LiTERATURE CITED}

Cameron, K. M., M. W. Chase, W. M. Whitten, P. J. Kores, D. C. Jarrell, V. A. Albert, T. Yukawa, H. G. Hills, D. H. Goldman. 1999. A phylogenetic analysis of the Orchidaceae: evidence from $r b c L$ nucleotide sequences. Amer. J. Bot. 86: 208-224.

Cameron, K. M. 2002. Molecular systematics of Orchidaceae: a literature review and an example using five plastid genes.Pp. 80-96 in: H. Nair (ed.). Proceedings of the 17th World Orchid Conference. Natural History Publications (Borneo) Sdn. Bhd., Sabah, Malaysia.

Cameron, K. M. 2004. Utility of plastid psaB gene sequences for investigating intrafamilial relationships within Orchidaceae. Molec. Phylogen. Evol. 31: 11571180 .

Chase, M. W., J. V. Freudenstein, K. M. Cameron \& R. L. Barrett. 2003. DNA data and Orchidaceae systematics: a new phylogenetic classification. Pp. 69-89 in: K. W. Dixon, S. P. Kell, R. L. Barrett \& P. J. Cribb (eds.). Orchid conservation. Natural History Publications, Kota Kinabalu, Malaysia.

Chase, M. W. \& H. G. Hills. 1991. Silica gel: an ideal material for field preservation of leaf samples for DNA studies. Taxon 40: 215-220.

Doyle, J. J. \& J. L. Doyle. 1987. A rapid DNA isolation procedure for small quantities of fresh leaf tissue. Phytochem. Bull. 19: 11-15.

Dressler, R. L. 1981. The orchids: natural history and classification. Harvard University Press, Cambridge, Massachusetts, USA.

Dressler, R. L. 1993. Phylogeny and classification of the orchid family. Dioscorides Press, Portland, Oregon, USA

Felsenstein, J. 1985. Confidence limits on phylogenies: an approach using the bootstrap. Evolution 39: 783-791.

Fitch, W. M. 1971. Toward defining the course of evolution: minimum change for a specific tree topology. Syst. Zool. 20: 406-416.

Graham, S. W., J. R. Kohn, B. R. Morton, J. E. Eckenwalder \& S. C. H. Barrett. 1998. Phylogenetic congruence and discordance among one morphological and three molecular data sets from Pontederiaceae. Syst. Biol. 47: 545-567.

Johnson, L. A. \& D. E. Soltis. 1998. Assessing congruence: empirical examples from moleculardata. Pp. 297-348 in: D. E. Soltis, P. S. Soltis \& J. J. Doyle (eds.). Molecular systematics of plants II: DNA sequencing. Kluwer Academic Publishers, Boston, Massachusetts, USA.

Johnson, S. D., H. P. Linder \& K. E. Steiner. 1998. Phylogeny and radiation of pollination systems in Disa (Orchidaceae). Amer. J. Bot. 85: 402-411.

Neubig, K. M., W. M.Whitten, B. S. Carlsward, M. A. Blanco, L. Endara, N. H. Williams \& M. Moore. 2009. 
Phylogenetic utility of $y c f 1$ in orchids: a plastid gene more variable than matK. Pl. Syst. Evol. 277: 75-84.

Posada, D. \& K. A. Crandall. 1998. Modeltest: testing the model of DNA substitution. Bioinformatics 14: 817-818.

Pridgeon, A. M., P. J. Cribb, M. W. Chase \& F. N. Rasmussen (eds.) 2005. Genera orchidacearum, Vol. 4. Epidendroideae (Part one). Oxford University Press, UK.

Rambaut, A. 1996. Se-Al: Sequence alignment editor, v2.Oa11. Oxford University, Oxford, UK. Available at website, http://evolve.zoo.ox.ac.uk/, last accessed 8 August 2002.

Reeves, G., M. W. Chase, P. Goldblatt, P. Rudall, M. F. Fay, A. V. Cox, B. Lejeune \& T. Souza-Chies. 2001. Molecular systematics of Iridaceae: evidence from four plastid regions. Amer. J. Bot. 88: 2074-2087.
Shaw, J., E. B. Lickey, J. T. Beck, S. B. Farmer, W. Liu, J. Miller, K. C. Siripun, C. T. Winder, E. E. Schilling \& R. L. Small. 2005. The tortoise and the hare II: relative utility of 21 noncoding chloroplast DNA sequences for phylogenetic analysis. Amer. J. Bot. 92: 142-166.

Sun, Y., D. Z. Skinner, G. H. Liang, \& S.H. Hulbert. 1994. Phylogenetic analysis of Sorghum and related taxa using internal transcribed spacers of nuclear ribosomal DNA. Theor. App. Genet. 89: 26-32.

Swofford, D. L. 1999. PAUP*: phylogenetic analysis using parsimony (*and other methods), version $4.0 \mathrm{~b} 10$. Sinauer Associates, Sunderland, Massachusettts, USA.

Thomson, J. D. \& P. Wilson. 2008. Explaining evolutionary shifts between bee and hummingbird pollination: convergence, divergence, and directionality. Int. J. Pl. Sc.169: 23-38. 